\title{
Noni Fruit (Morinda Citrifolia L) Extract as Traditional Body Scrub for Skin Care
}

\author{
Maspiyah, Amalia Ruhana \\ Department of Home Economics \\ Universitas Negeri Surabaya \\ Surabaya, Indonesia \\ maspiyah@unesa.ac.id
}

\begin{abstract}
The purpose of this study was to determine best proportion of noni fruit extract and rice flour as traditional scrubs as observed from the aroma, color, texture, and adhesion to skin. This was experimental study. The independent variables in this study were proportion of noni fruit extract and rice flour. Dependent variable was the quality of traditional scrubs. Data were collected using observation by organoleptic test that was carried out by trained and semi trained panelists. Data analysis used (one way) Anova test with SPSS program followed by Duncan test. Statistical test showed that the proportion of noni fruit extract and rice flour affected the quality of traditional scrubs. Duncan test results showed that the criteria of the best scrubs produce a distinctive noni fruit aroma. Color criteria, produce a yellowish white color. Texture criteria produce rather coarse texture. While criterion of adhesion to skin, produce a proportion which inherent to skin.
\end{abstract}

Keywords - traditional body scrubs; extracts of noni

\section{INTRODUCTION}

Cosmetics is a daily necessity that is regularly used for treatment purposes and beauty. Cosmetics production can be performed either in modern or traditional methods using materials from plants, leaves, fruits, roots, stems, seeds or spices [1]. Healthy skin means the skin that does not suffer from disease, both diseases that affect the skin directly or disease in the body that indirectly affects the health of the skin. Healthy skin appearance can be seen from the physical structure of skin, consisting of color, consistency, moisture, flexibility, thickness and texture of the skin [2].

In humid tropical region such as Indonesia, skin problems are varied, such as dry, dull, and premature aging. These skin problems are caused by external influences, due to the sun, water, air condition (AC), and the influence of other chemicals that do not conform to the skin so as the skin becomes dry, chapped, rough, scaly and looks wrinkled. Similarly, after doing outdoor activities, dirt and sweat accumulate so that they cover the pores which causes the skin becomes dull. To prevent and overcome worsened condition, we need a regular treatment with skin care, known as body scrubs. The use of body scrub is aimed to slough off dead skin cells to brighten the skin, making the skin smooth and clean, as well as to remove body odor through the materials used for scrubbing [3].

Scrubbing is done by rubbing on the entire surface of the skin gently and evenly. Scrubs process can also be interspersed with massage using massage oil. In addition to removing dead skin cells, scrubs will also make the body more relaxed because blood flows more smoothly, the skin becomes bright, smooth, and clean. Mardatillah et al research [4] results showed that traditional scrubs made from turmeric and rice flour smoothed the skin and exfoliated dead skin. However, this type of scrub can only be used for one time because it cannot survive longer than 24 hours. Various traditional herbal preparations on the market include, for example, yam, strawberry, green tea, aloe vera scrubs and many others. Traditional scrubs have many benefits, safe for the skin, and does not cause adverse side effects $[1,5]$.

This study used rice flour as the main ingredient in the manufacture of traditional scrubs. Rice flour can help increase collagen production that acts to improve skin elasticity [6]. Essential ingredient in rice, vitamin E, is able to refine and rejuvenate the skin. The substance gamma oryzanol in rice is capable of renewing the formation of melanin pigment and effective against ultraviolet [6]. Noni can be beneficial if it is used for skin care. The content of polysaccharides found in noni fruit can remove dead skin cells, improving skin tissue, so the skin will be soft and toned back. Noni also contains vitamin $\mathrm{C}$ with high antioxidant content so as to nourish properly when applied to the skin. Besides containing polysaccharides, noni also contain scopoletin, rutin, ascorbic acid, beta carotene, 1-arginine, proxironin, proxeroninase, iridoids, asperolusid, iridoid anthraquinone, fatty acids, calcium, vitamin B, amino acids, glycosides, and glucose [7] It also contains compounds like, morindon, rubiadin, and flavonoids [8]. The substance is mostly useful for skin care, to maintain skin softness, repair damaged skin and remove dead skin cells, as an antioxidant, eliminating body odor, neutralize irritated skin and reduce cellulite [9]

\section{MATERIALS Methods}

This study was an experimental study. The independent variable in this study was the proportion of noni fruit extract and rice flour. The proportion of noni fruit extract and rice flour used in this study were $\mathrm{X} 1=10$ grams of noni fruit extract: 90 grams of rice flour, $X 2=20$ grams of noni fruit extract: 80 grams of rice flour, and $\mathrm{X} 3=30$ grams of noni fruit extract: 70 grams rice flour. The dependent variable in this study was traditional scrub quality (Y). Scrubs quality are the physical properties of traditional herbal products that include scent, color, texture, and adhesion to the skin. Control 
variable in this study was the type of noni fruit and rice flour. The equipment used in making the mask must be the same, clean, and appropriate function. This study was conducted in Science Laboratory, Department of Family Welfare Education, Faculty of Engineering, State University of Surabaya. Microbiology test was conducted at Laboratory of Mathematics and Science, State University of Surabaya. In this study the design used was single factor design.

TABLE I. PROPORTION OF NONI FRUIT EXTRACT (GRAM) AND RICE FLOUR TO TRADITIONAL SCRUB

\begin{tabular}{|c|l|l|l|l|l|}
\hline \multirow{2}{*}{$\begin{array}{c}\text { Proportion of noni } \\
\text { fruit extract and } \\
\text { rice flour }\end{array}$} & \multicolumn{5}{|c|}{ Scrub produced (properties of the traditional } \\
\cline { 2 - 6 } & $\mathrm{Y} 1$ & $\mathrm{Y} 2$ & $\mathrm{Y3}$ & $\mathrm{Y} 4$ & $\mathrm{Y}$ \\
\hline $\mathrm{X} 1$ & $\mathrm{X} 1 \mathrm{Y} 1$ & $\mathrm{X} 1 \mathrm{Y} 2$ & $\mathrm{X} 1 \mathrm{Y} 3$ & $\mathrm{X} 1 \mathrm{Y} 4$ & $\mathrm{X} 1 \mathrm{Y} 5$ \\
\hline $\mathrm{X} 2$ & $\mathrm{X} 2 \mathrm{Y} 1$ & $\mathrm{X} 2 \mathrm{Y} 2$ & $\mathrm{X} 2 \mathrm{Y} 3$ & $\mathrm{X} 2 \mathrm{Y} 4$ & $\mathrm{X} 2 \mathrm{Y} 5$ \\
\hline $\mathrm{X} 3$ & $\mathrm{X} 3 \mathrm{Y} 1$ & $\mathrm{X} 3 \mathrm{Y} 2$ & $\mathrm{X} 3 \mathrm{Y} 3$ & $\mathrm{X} 3 \mathrm{Y} 4$ & $\mathrm{X} 3 \mathrm{Y} 5$ \\
\hline
\end{tabular}

The process of making traditional herbal extract of noni fruit and rice flour in this study was as follows: 1) preparing tools, the small basin, blender, spoon, sieve, measuring cup, scales, cup, tray, and oven 2) preparing the ingredients the noni fruit and rice. 3) The process of making traditional scrubs included: a) making extraction of noni fruit. The fruit was washed clean, free from dirt, then cut thin, air dried at $40^{\circ} \mathrm{C}$ for 2 hours. After drying, they were put into the extractor tool sheker then added with $96 \%$ ethanol ( $1 \mathrm{~kg}$ of noni fruit: 1 liter of ethanol), for 24 hours, then filtered to obtain clear viltration. These vents were mixed and fed into the vacuum evapolator at a temperature of $50^{\circ}-60^{\circ} \mathrm{C}$ until all ethanol was separated (3-4 hours) to obtain thick liquid of noni fruit. b) making the rice flour, where the rice was washed, dried, ground, then sifted. c) Weighing the extract of noni fruit and rice flour, then poured on each cup. Cup X1 was as much as 10 grams, cup X2 20 grams, and cup of X3 was 30 grams. d) weighing the rice flour. In cup X1 it was as much as 90 grams, $\mathrm{X} 2$ as much as 80 grams, and $\mathrm{X} 3$ as much as 70 grams. E) mixing the extract of noni fruit and flour in each cup while stirring evenly. f) after the third treatment was stirred evenly, all three were entered into the oven at a temperature of $50^{\circ} \mathrm{C}$ to dry. g) refining and sieving again using a filter. $\mathrm{H}$ ) the third treatment was kept back into the oven at the same temperature until it was completely dry.

Data collection technique in this study was observation method by using observation sheet. Observation method was performed to examine physical properties of traditional scrubs including scent, color, texture, and adhesion to the skin. The number of panelists in this study were 30 persons consisting of trained and semi-trained panelists. Data analysis was done with the help of computer program SPSS version 16. Data analysis technique used was analysis of variance (one way Anava). If the results showed no real effect, it was followed by Duncan test.

\section{RESULTS}

\section{A. Results}

Mean value of physical properties of traditional scrubs including scent, color, texture, and adhesion in each treatment is presented in Table II.

TABLE II. PHYSICAL PROPERTIES OF TRADITIONAL SCRUBS

\begin{tabular}{|c|c|c|c|c|}
\hline \multirow{2}{*}{$\begin{array}{l}\text { Proportion of } \\
\text { noni extract and } \\
\text { rice flour }\end{array}$} & \multicolumn{4}{|c|}{ Scrubs produce } \\
\hline & Aroma & Color & Texture & $\begin{array}{l}\text { Adhesion } \\
\text { power of the } \\
\text { body }\end{array}$ \\
\hline $\mathrm{X} 1$ & 2.23 & 2.00 & 3.73 & 2.73 \\
\hline $\mathrm{X} 2$ & 2.20 & 3.97 & 3.07 & 3.07 \\
\hline X3 & 2.97 & 3.00 & 2.70 & 3.33 \\
\hline
\end{tabular}

Table II shows the mean value of physical properties in each of the traditional scrubs as follows: 1) mean value of the aroma of the traditional scrub products was 2.23 to 3.20 . The highest mean (3.20) was in the proportion X2 has moderate aroma of noni fruit. Proportion X3 had mean values (2.97) of strong aroma. The lowest mean was on the product X1 (2.23) with the resulting aroma of weak aroma of noni fruit. 2). Mean color value in traditional body scrub products was 2 to 3.97. The resulting color of X1 (2.00) yields the lowest criteria of white color, X2 (3.97) yields a slightly yellowish white color criterion, and X3 $(3,00)$ yields a yellowish-white criterion. 3) Mean texture value of traditional body scrub products was 2.70 to 3.73 . The resulting texture of the proportion of $\mathrm{X} 1=$ 10 grams of noni fruit extract and 90 grams of rice flour (3.73) produced fine texture, $\mathrm{X} 2=20$ grams of noni fruit extract and 80 grams of rice flour (3.07) produced moderately fine texture, for the proportion of X3 $=30$ grams of noni fruit extract and 100 grams of rice flour (2.70) produced the lowest texture, the less fine one. 4) Mean value of adhesion power of the body scrub to the skin was 2.73 to 3.33 . The resulting adhesion of the proportion X3 (3.33) produced strong adhesion compared to proportion X2 (3.07) which was moderately adherent, while the least adhesive force was generated from the proportion X1 (2.73).

The result of one way anava test showed that the proportion of noni fruit extract and rice flour had effect on aroma, with $\mathrm{P}=0.000(\mathrm{P}<0,05)$, showing the influence of proportion of noni fruit extract and rice flour on the aroma of traditional scrub. Duncan's test shows the proportion of X3 and $\mathrm{X} 2$ produces more aromatic noni scrub, compared to X1.

The proportion of noni fruit extract and rice flour influenced on the color of the scrub, $\mathrm{P}=0.000(\mathrm{P}<0,05)$. There is influence of extract of noni fruit and rice flour proportion on traditional scrub color. Duncan test results showed that the proportion of $\mathrm{X} 2$ produced the best colored scrub, then X3, and at least was shown by X1.

The proportion of noni fruit extract and rice flour had effect on the texture of the scrub, $\mathrm{P}=0.000(\mathrm{P}<0,05)$. The Duncan test results showed the proportion of $\mathrm{X} 1$ yielded the best-textured scrub, then X2, and at least is shown by X3. The proportion of noni fruit extract and rice flour had effect on the adhesion of the scrub, shown by $\mathrm{P}=0,008<0,05$. Duncan test results showed that the proportion of $\mathrm{X} 3$ and $\mathrm{X} 2$ produced 
scrubs with better adhesion power compared with the proportion X1.

TABLE III. TRADItIONAL SCRUB Microbiology TeSt RESUlts

\begin{tabular}{|c|c|c|c|c|}
\hline \multirow{2}{*}{$\begin{array}{c}\text { Code } \\
\text { Repetition }\end{array}$} & \multicolumn{4}{|c|}{ X3 } \\
\cline { 2 - 5 } & $\mathbf{1}$ & $\mathbf{2}$ & $\mathbf{3}$ & Mean \\
\hline Day 0 & 0 & 0 & 0 & 0 \\
\hline Day 1 & 0 & 0 & 0 & 0 \\
\hline Day 3 & $10^{2}$ & $10^{2}$ & $10^{2}$ & $10^{2}$ \\
\hline Day 8 & $>10^{8}$ & $\begin{array}{c}\text { Un- } \\
\text { countable }\end{array}$ & $\begin{array}{c}\text { Un- } \\
\text { countable }\end{array}$ & $\begin{array}{c}\text { Un- } \\
\text { countable }\end{array}$ \\
\hline $\begin{array}{l}\text { Source: Microbiology Laboratory, Faculty of Mathematics and Science, State } \\
\text { University of Surabaya }\end{array}$
\end{tabular}

The results showed that traditional body scrub X2 from day 0 to day 2 was not overgrown with microbes. On the third day the microbes began to grow in a total of 102 , in the seventh day there were 104, and on the eighth day there were microbes of 108 colonies. According to the Decree of the Director General of Drug and Food Control of the Ministry of Health of the Republic of Indonesia No. HK.00.06.4.02894, which sets the standard for microbial test on scrub preparations, the maximum total plate number is 105 colonies. So face mask can be used at best until the seventh day only

\section{DISCUSSION}

Duncan's advanced test shows that in traditional scrubs made from noni fruit extract and rice flour, the proportion of $\mathrm{X} 3$ and $\mathrm{X} 2$ produced noni aroma, because in both proportions the amount of noni fruit extract was higher, although the amount in each proportion was different. The proportion of X1 produced moderate noni aroma. The distinctive aroma that comes from Noni fruit on the three products of scrub was remarkable. This is because the more the amount of noni fruit extract, the more sharp the resulting aroma. Noni fruit has an unpleasant aroma due to the mixing of caproic acid and capric acid in the fruit [8]. Although the aroma will disappear if extracted, but in large amounts the aroma will slightly arise compared with that in the small amount [9].

Different proportion of noni fruit extract and rice flour produces different colored scrub. The more the number of noni fruit, the more yellowish the resulting color. The color of the scrub produced in this study was white to yellowish white. The color produced by scrub is yellowish white color. Yellowish white color is produced from noni fruit and white color is produced from the rice flour, so if both colors are mixed it will produce white to yellowish white color [10,11]. The yellowish white color of noni fruit comes from anthocyanin substances that are useful as antioxidants. Anthocyanins are the pigments of the water-soluble flavanoid group. Antocyanin and some other flavonoids are beneficial in the world of health as anticarcinogen, antibacterial, and antiviral [11].

The physical properties of the scrub produced different textures on the three comparisons. This was due to different proportion of noni fruit extract and the rice flour. X3 scrub product produced coarser texture because the $\mathrm{X} 3$ product contained more noni fruit extracts than $\mathrm{X} 1$ and $\mathrm{X} 2$ products. Rice flour has a fine texture according to the standard of refined rice flour contained in SNI 01-3451-1994 which states that $99 \%$ rice flour is able to escapes sift. The physical properties test on the texture of the scrub yields that the scrub product X1 and X2 produced fine texture criteria. Sasri's study on traditional masks made of strawberry and tapioca puree found that the more pure the strawberries, the more grainy the mask granules produced [12].

Different proportions of materials produced different scrub adhesion. In the application process on the skin, scrub is mixed using water with the same dose on each product that is 4 grams of mask powder with $30 \mathrm{cc}$ water. After mixing with water, all three products could adhere to the skin because the rice flour on the scrub served as adhesive and thickener. This is consistent with Mardatillah's finding that rice flour is used as a thickener, filler, and binder in food industry $[4,12,13]$. After being smeared on the skin, the scrub gives cold sense and when the scrub is semi-dry it is easily rubbed and cleaned, so it will smooth the skin and exfoliate dead skin cells. In accordance with the standards of scrub preparations according to SNI 16-6070-1999, when applied to the skin, cold-scrub preparations may cause a sense of toned, and if rubbed it will smooth the skin.

\section{CONCLUSION}

The proportion of noni fruit extract and rice flour has influence on the physical properties of traditional scrubs including aroma, color, texture, and adhesion to the skin. The aroma in proportion X2 was the best. The scrub color in proportion $\mathrm{X} 2$ was the best. The scrub texture in proportion $\mathrm{X} 1$ was the best, and the adhesion of the scrub in proportion $\mathrm{X} 3$ was the best.

\section{ACKNOWLEDGMENT}

This study was financial support from the Simlitabmas Kementerian Riset Teknologi dan Pendidikan Tinggi Indonesia.

\section{REFERENCES}

[1] Pachianathan, N and Kandasamy, R, "Skin care with herbal exfoliants, Functional Plant Science and Biotechnology 5", Global Science Books, (Special Issue 1) pp.94-97,2011

[2] Sandby-Moller J, Poulsen T, Wulf HC, "Epidermal thickness at different body sites: relationship to age, gender, pigmentation, blood content, skin type and smoking habits, Acta Derm Venereol", 2003, vol.83, pp. 410-3

[3] Baurin N, Amoult E, Scior T, Do QT, Bernard P, "Preliminary screening of some tropical plant for anti-tyrosinase activity", Jounal of Ethnopharmacology, vol. 82, pp. 155-158, 2002.

[4] Mardatillah, "Lulur berbahan kunyit dan tepung beras (Scrub made from turmeric and rice flour)". Online journal, Surabaya : Fakultas Teknik Universitas Negeri Surabaya, 2013.

[5] Shuster S, Black MM, McVitie E, "The influence of age and sex on skin thickness, skin collagen and density, Journal of Dermatology", vol. 93, pp. $639-43,2005$

[6] Katekhong, W and Charoenrein S, "Effect of rice storage on pasting properties, swelling and granular morphologi of rice flour, Asian Journal of food and agro-industry" ISSN 1906.3040, 2011 
[7] Yanine Chan-Blanco et al, "The noni fruit (Morinda citrifolia L.): Areview of agricultural research, nutrition, and therapeutic properties, Journal of Food Compotition and analysis", vol.19, issues 6-7, pp.645654, September-November 2006

[8] Mathivanan N and Surendiran G, "Chemical and Biological properties of Morinda spp. International Journal Noni Research", vol. 2, pp. 1-2 January-July 2007

[9] Hsin-Lun Huang, et al., “Antiadhesion and Anti-inflammasion Affects of Noni (Morinda citrifolia) Fruit Extracts on AGS Cells during Helicobacter pylori Infection, Journal Agricultural Food Chemical.", vol.62 (11),pp 2374-2383, DOI: 10.1021/jf405199w, February 14, 2014.
[10] Wang Kuo-Hsien, et al, "Cosmetic applications of selected tradisional Chinese herbal medicines, Journal of Ethnopharmacology 106", http://doi.10.1016/j.jep.2006.01.010, pp. 253-359, 2006

[11] Singh D.R, Sunder J, and Srivastava C, "Peptide and mineral profile of morinda citrifolia L fruit and leaves, International Journal of Noni Research", vol. 2, pp.1-2, 2007

[12] Sasri, I. W,. et al, "Masker Tradisional berbahan strowberi untuk perwatan kulit normal, (Tradisoonal mask of strawberry for normal skin care)" online Journal, Universitas Negeri Surabaya, 2013.

[13] Sharma HD, Paramesh R, "Trends in aging and skin care: Ayurvedic concept. Journal of Ayurveda and Integrative Medicine", 1:110-113, 2010 